DOI: $10.20472 / \mathrm{IAC} .2017 .030 .021$

\title{
CAMERON MCCARTHY
}

University of Illinois, United States

\section{UNDERSTANDING THE WORK OF AESTHETICS IN MODERN LIFE}

\begin{abstract}
:
NeoMarxists scholars of education writing on urban life have tended to place aesthetics on the boundaries of critical practices, treating aesthetics as a surplus set of practices that could only be made fully usefully relevant when added on to a more concentrated attention to economy and politics. The main claim I want to make in this presentation is that aesthetic practices now underwrite the fibre of everyday modern life. As Arjun Appadurai usefully argues in Modernity at Large and History as Cultural Fact aesthetics are no longer to be simply understood as the practices of the artist, a maverick citizen creating images about the past, present and the future of human existence. But aesthetics are linked to the work of imagination of ordinary people and connected even more earnestly to the work of capitalism and its reorganization on a global scale. Contrary to the neoMarxist tradition, aesthetic practices are at the epicenter of lived experience and the commodified and institutional practices of modern societies. These practices, as CLR James allerted us to in American Civilization, constitute a great window on contemporary life revealing central contradictions, tensions and discontinuities. This, after all, was the burden of the Latin American and Caribbean Writers Forum of Intellectual and Cultural workers (George Lamming, Gabriel Garcia Marquez and others) who had publicly opposed the Reagan government invasion of Grenada in 1983. They insisted, as did Arnaldo Roche-Rabel, that aesthetics were imbricated in economy and politics-that artistic militancy is critical to production of democracy. The work of aesthetics is crucial to any formula for democratic transformation.

In this presentation, I would like to call attention to the following issues. First, the entanglement of the diffusion of modernization to the third world in aesthetics. Second, I want to point as well to the deepening role of aesthetics in the organization capitalism in the new millenium in which we live. Third, I will discuss briefly the crisis of language that the aestheticization of everyday life has imposed/precipitated in neoMarxist efforts to grasp the central dynamics of comtemporary society. The latter has led to a depreciation of the value and insightfulness of neoMarxist analysis in our time-old metaphors associated with the class, economy, state ("production," "reproduction," "resistance," "the labor/capital" contradiction) are all worn down by the transformations of the past decades in which the saturation of economic and political practices in aesthetic mediations has proceeded full scale.
\end{abstract}

\section{Keywords:}

Cultural Work, Aesthetics, Late-Modern Life, NeoMarxist Theories

JEL Classification: Z11 


\section{Introduction}

Let me begin this paper with a necessary postcolonial detour as to how I came into the academic discipline of cultural Marxism and thereafter to talk about the status of aesthetics within cultural studies in this contemporary moment. In the paper throughout the postcolonial context is held up as a standpoint of knowledge production for the purpose of reflecting deeply on strands of cultural Marxism such as that evinced in cultural studies. I guess I should begin by stating that I see myself as a postcolonial subject growing up in a large working class family in Barbados, a former British colony, as one of the unlikeliest candidates for an academic career as a cultural Marxist scholar in the human disciplines in the United States. It all begins with an intense exposure to a classical colonial education at a high school called Combermere founded in 1695 as a Free School first endowed by sugar cane planter benefactor Colonel Henry Drax and named after a British Lord, Lord Combermere who in 1819 raised 22,630 pounds to erect a building for the school that would bear his name. The name Combermere which has a further prehistory linked to the Benedictine monks who founded Combermere Abbey in Cheshire, England in 1133 would be associated with high quality education for indigent white and black and brown working class boys in the island. There I was reared in the humanities, so to speak, a classical liberal arts education, in which I studied Shakespeare, Chaucer, Eliot, Beckett, Jane Austin, the War poets Wilfred Owen, Sigried Sasson and Robert Graves etc along with Latin and French and Spanish, Mathematics and the Sciences. But alongside this classical education, this "collection code," as Basil Bernstein would call it, I was exposed to radical ideas coming from North America in the form of the messages and themes of soul music and the Black power movement. It was the 60s and the writings of Ernest Hemmingway, Men without Women, For Whom the Bell Tolls, Islands in the Stream (books set in Spain and Cuba respectively), Elridge Cleaver's Soul on Ice, the writing $s$ of J. Rapp Brown, James Baldwin's remarkable Nobody Knows My Name, No Name in the Street, Another Country, Giovanni's Room, Another Country, Go Tell it on A Mountain and The Fire Next Time, Herbert Marcuse's student, Angela Davis soul searching call for justice all served as an alternative curriculum. I tested into this elite single-sex high school at the age of 10 , while ironically the children of the British Harbormaster, for whom my mother worked, failed. You must understand this irony in a little more detail. The exam that I sat for transfer from elementary to secondary school was set and normed in England and sent down to the colony to be administered to Barbadian kids regardless of class or race or gender. Colonialism sometimes utterly refuses subtlety. We sat the exam in Barbados and then it was sent back there in England to be graded. That the children of my mother's employer 
failed and that her own kids succeeded was a triumph of sorts of the preparation of my father, Harold, who was a monitorial math teacher at a very young age. Such is the fantastic/fantasmic origins of my academic career. I was on a track if you will, that would take me to a first degree in English Studies and the Political Sciences-a diasporic flight to Canada to do a degree in International Studies in Education at the University of Alberta. And, later south across the border again, to do an apprenticeship with Michael Apple, as the resident social phenomenologist, (student of Dwayne Huebner and Maxine Greene-two of the most influential scholars in the educational field) in curriculum studies at the University of Wisconsin-Madison. My doctoral degree was in Curriculum and Instruction, Sociology and Communication Arts. I guess I have always been a disciplinary cross-dresser-a burnished alloy of several things and elements. I have always thought that scribbled and etched on the black body are more markers of the ages than words could ever say. This polysemic text of academic preparation has allowed to me to cross the insulated borders of literary and philosophical work in the humanities to theoretical work and methodological training in the social sciences. I teach and research now in the Global Studies in Education and the Institute for Communications Research at the University of Illinois.

\section{\{\{Addressing Cultural Studies on the Topic of AestheticsHeading for Here $\}\}$}

Given this brief biographic coda, what does postcolonial author make of the key terms that motivate this essay? What do I mean by "recession"? What do I mean by "culture"? What do I mean by aesthetics? By recession, I am not really referring to the economic downturn particularly. I am referring to something related but separate. I am referring to the peculiar diminution of intellectual autonomy in our times paradoxically in educational institutions. By culture, I am not referring to the idea of refined practices or a court of appeal, Matthew Arnold's "all that is sweetness and light" (CHECK CITATION). I am referring to the production and circulation of images in stratified contexts-a matter over which in cultural studies we use theory to problematize and unpack taken-for-granted experiences and practices. I privilege the understanding of context not as a background phenomenon but as radical relationality and the triangulation of artifacts, language or discourse, practices, events and structures. And I explore, and I am deeply interested in, the operation of power. I am attentive to inequality. In talking about method, I am not merely talking about technique, I am talking about an orientation to knowledge. In cultural studies, as in postcolonial theory, we champion a methodological model of multidisciplinarity, plurality and complementarity. In talking about aesthetics, I am referring to strategies of interpretation of human relations and transactions in which style and form are the content of life's self-fashioning. The circulation of such forms has 
powerful effects and generates distinctive energies in human affairs that can overrun narrow-mindedness and, as Cornel West might suggest, beat back or trash particularisms. As a scholar I engage with cultural studies, as Walter Rodney, who wrote How Europe Underdeveloped Africa, use to say, as a "critical friend' and give this radical tradition of scholarship critical support. I am not an acolyte!

\section{$\underline{\text { Reading Aesthetics without Guarantees }}$}

A postcolonial dialogue with cultural studies should start off with a foundational text. I use Paul Willis's Learning to Labor as a critical point of departure for thinking about the work of aesthetics in the fates and fortunes of the marginalized proletariat in the peripheries of the First and the Third Worlds. Indeed, when I consider Learning to Labor, I can not help thinking about the rising tide of denunciations of cultural studies both from the Left and the Right over the years. One can, for example, call to mind Judith Williamson's extraordinarily blunt rejection of what she calls "Left-wing academics picking out strands of subversion...in every piece of pop culture from Street Style to Soap Opera" (Williamson, 1986, pp.14-15). Of course, the academic world is saturated with bad faith punditry, soothsaying, and the empiricist declarations of Cassandras. As perhaps a compensatory reflex, critical theorists are genre prone. No sooner is a new theoretical line of inquiry announced, than a whole new congregation gathers, a field of affiliation is declared, even as its enemies, theorists on the other side, gather, lying in wait in the shadows. Well, the end is always near, at the closest "post." Reading/writing/researching radicals live precarious lives and so forth. But there is something nagging in Williamson's statement, it concerns the attack on texts and textualism, the opposition of that fatal couplet "text" versus "experience," and the attendant cynicism about the politics of everyday life and popular investments in taste and style. These are all issues that are raised directly or obliquely in Willis's work, particularly his The Ethnographic Imagination and his Common Culture.

Customarily, cultural studies and neoMarxist scholars of education writing on urban life have tended to place aesthetics on the boundaries of critical practices, treating aesthetics as a surplus set of practices that can only be made fully relevant when added on to a more concentrated attention to economy and politics. I argue here against this tradition. Instead, I maintain that aesthetic practices now underwrite the fiber of everyday modern life. As Arjun Appadurai usefully points out in Modernity at Large (1996) and The Future as Cultural Fact (2013), aesthetic practices are no longer to be simply understood as the practices exclusive to the artist-a maverick or charismatic citizen creating selective images about the past, present and the future of human existence. But, aesthetic 
practices are linked to the work of the imagination of ordinary people and connected even more earnestly to the work of capitalism and its organization and re-organization on a global scale.

I therefore, first, want to discuss the entanglement of aesthetic discourses in the diffusion of modernization and developmentalism to the Third World. Second, I want to point as well to the deepening role of aesthetics in the organization of capitalism in the new millennium in which we live. Third, I discuss briefly the crisis of language that the aestheticization of everyday life has precipitated in neoMarxist efforts to grasp the central dynamics of contemporary societies. The latter development has led to a depreciation of the value and insightfulness of neoMarxist analysis in our time. We live in an era in which old metaphors associated with Marxism-concepts such as "class," "economy," "state," "production," "reproduction," "resistance," "the labor/capital contradiction", "reality" and "fiction," "ideology" versus "truth," "materiality" and "immateriality" are being worn down by the transformations of the past decades in which the saturation of economic and political practices in aesthetic mediations has proceeded full pace (Klein, 2000). I will conclude by pointing toward the existential cosmopolitanism latent in third world and minority creations as perhaps offering a way out. Let me now turn to a discussion of the historical context of the integration of aesthetics into commerce.

\section{The Marriage of Aesthetics and Economy}

The long shadow of the integration of aesthetics and economics in the elaboration of the capitalist order can be tracked back to before the turn of the twentieth century in the production of new markets for the ever-expanding range of capitalist goods and services and the generation of consumer durables. These "luxuries" of personal style were in their everyday utility, if not necessity, expanding middle-class consumption patterns to the working class ("A growing market in cheap luxury items allowed others [the lower and working classes] to purchase the symbolic accoutrements of status," [Ewen, 1988, p. 59]). Within this set of developments, deepening patterns of aestheticization of advertising, the imbuement of commercial products with sensuosity, flair and feeling, and so forth generated a leveling effect in the processes of class representation and helped to transform agrarian and immigrant actors into the new acquisitive urban subjects. The working class could try on the uniforms of the upper classes, explore their ways of life through the glow and illumination of bric-a-brac and through consumer credit and loans acquire the imitation furniture, jewelry, and items of leisure that mirrored aristocratic existence. Aesthetic practices integrated into economic form were now performing the pedagogy of molding the new subjectivities of the modern age-less in collision with 
capital in the classical nineteenth century sense identified by Friedrich Engels in The Condition of the Working Class in England (1845/1987) but more in besotted communion with the spectacular array of consumer products capitalism had strewn in their wake. "Progress," the narrative of one's life trajectory and imagined futures of linear accumulation, would now be marked by the range and capacity of one's consumption. To be a true citizen in the modern society was to be a dedicated consumer.

\section{Selling Modernization and Consumerism to the Third World}

This model of progress, proletarianized and internationalized by the middle of the twentieth century, would be taken full scale to underdeveloped countries around the globe. It would be embodied in Coke and Pepsi ads, the family size Coca Cola drink, the cultural translation performed by the films, musicals, popular songs, etc that entered the Third World through cinema houses, and especially, radio and newspaper, cartoons, and the lure of the new sleek looking surfaces of consumer durables and household electronic appliances. Here, retail and hire purchase practices of the lower orders summarized the needs of the masses for something more than material want. These practices of borrowing today and paying tomorrow underlined a fueled working-class interest in comparative affluence, taste, and leisure- a desire to expand and materialize freedom by codifying taste and style and by integrating the aesthetic and erotic, leisure and pleasure practices into their rigorously subordinated lives defined by industrial parks and in agrarian obligation.

Musicals such as The King and I (1956), The Sound of Music (1965), soap operas such as Portia Faces Life (a radio soap opera that was started in 1940s and later taken up for television broadcasting by CBS in the 1950s) offered aesthetic solutions to the problems of necessity and want in the Third World. These popular cultural productions propagated ideas such as the inviolability of contract and the value equivalence involved in the process of exchange of labor power for wages. They extended a shimmering imaginary plane of existence linking the metropolis to the periphery latent with needs and saturated with unfulfilled desires. These aesthetic works suggested that Third World life, linked to tradition and agrarian organization and imagination, was flawed, oppressive, backwards (a neo-Marxist claim as well!). This type of enlightenment narrative was propagated, for example, in highly popularized musicals such as the The King and I. Circulated through radio and television, The King and I made popular the modernization dilemma of the old traditions of Siam (what is now Thailand) versus the suppressed wish fulfillment of Siam's 
people, particularly their capacity for individual action and choice. The King and I ultimately set the capriciousness of the absolutist state against the visions of constitutional democratic nation-state. The way out of cultural miasma and backwardness to enlightenment was provided in the person of an English schoolteacher, Anna, who would carry out the work of cultural incorporation and translation. The cultural and philosophical forms of modernization-the right to private property, the capacity of the workers to sell their labor power, and the deification of Western democratic traditions - are all underscored in this musical in which a half-naked king, with Anna's help, must reconstitute his relations to his subjects and retool himself as a comprador agent of capitalism's expansion in south east Asia.

The aestheticization of the economic - capitalism with a human face-sold the Third World on the modernization theories of Western policy intellectuals such as Daniel Lerner, Harold Lasswell and William W. Rustow. The "passing of traditional society," as Lerner (1958) called it, involved that fearful asymmetry of contractual agreement to exploitation and excavation of the resources of the native and her land, along with state enforced guarantee of the privileged status of the right to private property that multinationals and mercantile local elites so intensely craved. The development gap between the Third World and the First could be jumped by the expansion of the consumerist culture of possessive individualism and the wholesale adoption of the infrastructure of industrialized production by "overseas" territories. Just as new streets where being paved for industrialization by invitation in Puerto Rico and Barbados-the sweet middle-class life of the "Brady Bunch" and later the "Partridge Family" presented itself through television as the embodiment of the one and only true heaven, as the buoyant endgame in the struggle for happiness (Lasch, 1991). Why couldn't a woman be more like a man (My Fair Lady [1964])? Why couldn't we Third World Siams be more like the enlightened West?

It was, in part, this logic of modernization, the embeddedness of the developmentalist project, the dream of plenitude and progress, the work of the imagination of ordinary Third World people that delivered the Pakis and the Jamaicans to the land of the Lads in pursuit of the Holy Grail of the better life and the material rewards of capitalism. What we confront in the ocular opposition of the immigrant other to the "lads" in Learning to Labor is this abridgement of a continuous line or movement of disembeddedness, displacement and transformation in an imaginative and spatial geography that extends the aspirations of the Jamaicans, the West Indians, the Pakis, the Indians and Bangladeshis from the periphery to beach heads in Brixton and Manchester, and elsewhere in England. The full significance of what this movement would mean in the changing terms of globalization 
was indeed far more fully recognized in the popular films The Full Monty (1997) and Billy Eliot (2000) and more recently, This is England. To understand these dynamics more clearly we must now turn to a consideration of the role of aesthetics in everyday life.

\section{$\underline{\text { Aesthetics and Everyday Life }}$}

The role of aesthetics in everyday life has deepened in the last few decades with the rising importance of computerization and media-driven technologies. The work of aesthetics is not simply now embodied in the selling of messages and images but in the very construction of products and constituencies of affiliation in the new millennium. It is that whole area of stylization of the self, self-regulation, surveillance and the selfmanagement of everyday life that Foucault discusses in his History of Sexuality volumes. But the processes of aestheticization also reach deeper into the marketing and circulation of goods and services, the proliferation of labels and the redirection of difference and diversity towards the new vending machines of choice. As the author of No Logo (2000) and the Shock Doctrine (2007) Naomi Klein insisted some years ago, it is the aesthetics of entrepreneurial identities and labels, logos and brands that have displaced the manufacture of products as the heart and soul of what makes post-Fordist capitalism tick:

The astronomical growth in the wealth and cultural influence of multinational corporations over the last fifteen years can arguably be traced back to a single, seemingly innocuous idea developed by management theorists in the mid-1980s: that successful corporations must primarily produce brands not products. (Klein, 2000, p. 3)

Everywhere smart capital is running away from the materialization of dense product inventories, costly overheads and static models of factory organization and opting instead for the cultivation of new bonds of consumer affiliation and labeling, relying on the faithful consumer to spawn markets by parading the labels of branded distinction in their natural habitats. The consumer's body and its extension by hand held machines such as the mobile phone, the iPad and iPod have become the new interactive canvases of commodity fetishism. And, it is in this framework of cultural oversupply that the modern consumer tries on new identities and directs and re-directs practices of self-correction and self-modulation. Transnational corporations such as Starbucks and Nike now brand new ecumenical communities with their labels like so many tattoos on the social/global body. And so, ethnic, class and gendered communities are now coalescing around practices of consumption and patterns of taste rather than around production relations or ancestry, or geography, or biology (Bourdieu, 1984; Dolby, 2001). The language of the 
new aesthetically branded world now registers the new ecumenical orders of feeling and the organization of affect and taste. As Manuel Castells tells us in The Rise of the Network Society (2000), these ecumenical orders overlap with the traditional collectivities of class or race or gender, but in the most frenetic and unpredictable of ways. This new aestheticism has generated a new cannibalism as the modern actor seeks refuge in ever more savage intensities and hybridities. Attachments to subject positions are now more precariously saturated.

\section{NeoMarxist Scholarship and the Shifting Terrain}

This shifting terrain of identity and affiliation has overtaken neo-Marxist scholarship in education. Categories and metaphors that had been relied upon in the past to unscramble social relations and dynamics now seem challenged by the new circumstances of contemporary education, work, and leisure. The formation of interests, distinctions, needs and desires seem now to be so susceptible to an endless array of permutations. The framework of analysis that linked education, to capitalist employers, to factories, to the nation-state, and so forth is no longer serviceable as the coordination of economic and symbolic production is now re-articulated along multiple sites in a global process of marketing, branding and outsourcing of goods and services. Much of the limitation of contemporary neoMarxist discourses in addressing the dynamic movement of cultural and economic capital today has to do with a tendency towards a residual structuralist realism that both reifies and privileges notions of an authentic working class, a territorially-bounded nation-state and an economy understood in terms of the language of commodity production and accumulation. What these theorists need to recognize, as Naomi Klein (2000) suggests, are the new trends that point to a deepening reorganization of capital. Within these developments symbolic mobilization is now an ascendant practice. Capitalist industries are divesting their inventories of commodities and investing in cultivating label affiliation, brand loyalty, and esprit de corps among the consuming population. Style and taste now drive the economic as ecumenical communities are fabricated in the uniforms of Nike or Gap or Hilfiger. It is the royal consumer whose newly dressed body serves as a mobile billboard for the corporate enterprise of Nike, Starbucks, Barnes and Nobles, Adidas, and so forth. The new consumer is the new citizen whose aesthetics of existence are now ever more deeply imbricated in a universalization of the entrepreneurial spirit and the propagation of the redemptive neoliberal value of choice. Nowhere do we see this cultural morphing of capital and the citizen more than in schooling. Students now approach their school and university curricula as the savvy consumer shopping for courses. And, courses are weighted by 
educational administrations on the basis of their "drawing power"-the numbers of enrollees per class (Miyoshi, 1998).

Xxx The new consumer is the new citizen whose aesthetics of existence are now ever more deeply imbricated in a universalization of the entrepreneurial spirit and the propagation of the redemptive neoliberal value of choice. Nowhere do we see this cultural morphing of capital and the citizen more than in schooling. Students now approach their school and university curricula as the savvy consumer shopping for courses. And, courses are weighted by educational administrations on the basis of their "drawing power"-the numbers of enrollees per class.

We have reached a stage in this millennium where the old "conflict" versus "consensus" metaphors do not seem to apply. Instead of models based on conflict and resistance, increasingly social groups are being defined by overwhelming patterns of transnational hybridities, new forms of association and affiliation that seem to flash on the surface of life rather than to plunge deeper down into some neoMarxist substructure. Paul Willis nationally and geographically-bounded Lads are now being replaced by Hisham Aidi's banlieusard diasporic youth formulating their powerful musical critiques of the French State and their protests against living conditions of immigrants by melding electronically relayed African American hip hop with Sufism and new North African poetry (Aidi, 2014). The lads have been replaced, too, by Jenny Kelly's Afro-Canadian youth who are patching together their identities from the surfeit of signs and symbols crossing the border in the electronic relays of US television, popular music and cyber culture (Kelly, 2004).

All these developments are turning the old materialism versus idealism debate on its head. It is the frenetic application of forms of existence, forms of life, the dynamic circulation of and strategic deployment of style, and the application of social aesthetics that now govern political rationalities and corporate mobilization in our times. The new representational technologies are the centers of public instruction providing the forum for the work of the imagination of the great masses of the people to order their pasts and present and plot their futures. The massive work of textual production is a socially extended project producing the cultural citizen in the new international division of labor.

I want to end here by pointing to powerful visionary energies. I think here of the work of the French cultural theorist, Jacques Attali. In his book Noise, he addresses the deeply condensed, even prophetic meanings circulating in contemporary aesthetic work. On the other side of the circulation of forms consolidating market power has been the aesthetic works of postcolonial imagination, their critiques of capitalism and the parables of 
modernization. These visionary frameworks parallel the rise of cultural studies in England and the Frankfurt School in Germany. They also run against the strong modernization push of US policy onto the Third World. Much of the value of these alternative aesthetics has fallen outside the prism of cultural studies analysis. The work of painters such as Aubrey Williams, Guyana Dreaming, the novels of Wilson Harris such as Palace of the Peacock setting the test of the integration of opposites, colonizer and colonized in Donne's dream kingdom or in the character of Idiot Nameless of Companions of the Night and Day who has the falling sickness in Mexico City plunging into pre-Columbian past. Thus the work of Gordon Bennett questions the narratives of settlement, enlightenment and modernization in his dialogue with Haitian American artist, Jean Basquiat. The movement and alternative reference of African American music within intimate platform of the Black Atlantic is still to receive a proper and meaningful documentation in cultural studies. The rise of dependency theory in Latin America focused in Chile and in some ways embodied in the poetry of Neruda and Mistral. The great irony here was that these alternative visions paralleled the moment of the rise of theory of cultural resistance associated with the British white working class and in the scholarship of its leading purveyors on either side of the Atlantic from Willis, MacRobbie, and Young to Giroux. It is to this postcolonial aesthetic work that we might chose to turn for edification on emancipation...the great longing for what Ornette Coleman called harmolodics or Sun Ra's ecological admonition that "space is the place" represent the voices of an alternative existential cosmopolitanism that might put our present historical moment in perspective in our quest for transcendence and transformation.

\section{References}

Appadurai, A. (1996). Modernity at LargeThe Cultural Dimensions of Globalization. Minneapolis, MN: Minnesota Press.

Appadurai, A (2013). The Future as Cultural Fact: Essays on the Global Condition. New York: Verso.

Bourdieu, P. (1984). Distinction. Harvard University Press

Castells, M. (2000). The Rise of the Network Society (2 ${ }^{\text {nd }}$ Edition) Oxford: Blackwell.

Dimitriadis, G, \& McCarthy, C. (2002). Urban renewal: Gordon Bennett's notes to Basquiat (9/11). In, G. Bennett, Notes on Basquiat (pp. 1-4). Adelaide, Australia: Greenaway Art Gallery.

Dolby, N. (2001). Constructing Racial Selves. Albany, NY: SUNY Press.

Engels, F. (1845/1987). The Condition of the Working Class in England. London: Penguin. 
Ewen, S. (1988). All Consuming Images. New York: Basic Books.

Foucault, M.(1978). History of Sexuality, Volume One. New York: Vintage.

Foucault, M. (1985). The Use of Pleasure. New York: Vintage.

Foucault, M. (1986). The Care of the Self. New York: Vintage.

Giddens, A. (1990). The Consequences of Modernity. Cambridge, U.K.: Polity Press.

James, C.L.R. (1993). American Civilization. London: Blackwell.

Kelly, J (In press). Borrowed Identities. New York: Peter Lang.

Klein, N. (2001). No Logo. London: Flamingo.

Klein, N. (2007). The Shock Doctrine. New York: Picador.

Lasch, C. (1991). The True and Only Heaven: Progress and Its Critics. New York: W.W. Norton.

Lerner, D. (1958). The Passing of Traditional Society: Modernizing the Middle East. New York: Free Press.

Miller, T. (1998). Technologies of Truth. Minneapolis, MN: Minnesota Press.

Miyoshi, M. (1998). "Globalization," culture and the university. In, F. Jameson \& M. Miyoshi (Eds), The Cultures of Globalization (pp. 247-272). Durham, N.C.: Duke University.

Roche-Rabell, A. (1996). Under a total eclipse of the sun In, R. Hobbs. Arnaldo Roche-Rabell-The Uncommonwealth (p. 44). In R. Hobbs. Seattle, WA: University of Washington Press.

Sarup, M. (1996). Identity, Culture and the Postmodern World. Athens, Georgia: The University of Georgia Press.

Walcott, D. (1970). What the twilight says. In, D. Walcott, Dream on Monkey Mountain and Other Plays (pp. 3-40). New York: Farrar, Straus and Giroux.

Williamson, J. (1986, September). The problems of being popular. In, New Socialist, pp. 14-15.

Willis, P. (1977). Learning to Labor. New York: Columbia University Press.

Willis, P. (2000). The Ethnographic Imagination. Cambridge, U.K.: Polity Press. 